\title{
Thermotolerance and molecular chaperone function of the small heat shock protein HSP20 from hyperthermophilic archaeon, Sulfolobus solfataricus $P 2$
}

\author{
Dong-Chol Li • Fan Yang • Bo Lu • Dian-Fu Chen • \\ Wei-Jun Yang
}

Received: 3 August 2011 /Accepted: 7 August 2011 / Published online: 20 August 2011

(C) The Author(s) 2011. This article is published with open access at Springerlink.com

\begin{abstract}
Small heat shock proteins are ubiquitous in all three domains (Archaea, Bacteria and Eukarya) and possess molecular chaperone activity by binding to unfolded polypeptides and preventing aggregation of proteins in vitro. The functions of a small heat shock protein (S.so-HSP20) from the hyperthermophilic archaeon, Sulfolobus solfataricus $P 2$ have not been described. In the present study, we used real-time polymerase chain reaction analysis to measure mRNA expression of S.so-HSP20 in S. solfataricus $P 2$ and found that it was induced by temperatures that were substantially lower $\left(60^{\circ} \mathrm{C}\right)$ or higher $\left(80^{\circ} \mathrm{C}\right)$ than the optimal temperature for $S$. solfataricus $P 2\left(75^{\circ} \mathrm{C}\right)$. The expression of S.soHSP20 mRNA was also up-regulated by cold shock $\left(4^{\circ} \mathrm{C}\right)$. Escherichia coli cells expressing S.so-HSP20 showed greater thermotolerance in response to temperature shock $\left(50^{\circ} \mathrm{C}, 4^{\circ} \mathrm{C}\right)$. By assaying enzyme activities, S.so-HSP20 was found to promote the proper folding of thermodenatured citrate synthase and insulin B chain. These results suggest that S.so-HSP20 promotes thermotolerance and engages in chaperone-like activity during the stress response.
\end{abstract}

Keywords sHSP·S.so-HSP20 - Sulfolobus solfataricus P2

D.-C. Li $\cdot$ F. Yang $\cdot$ B. Lu $\cdot$ D.-F. Chen $\cdot$ W.-J. Yang $(\bowtie)$

College of Life Sciences, Zhejiang University

and Key Laboratory of Conservation Biology for Endangered

Wildlife of the Ministry of Education,

Hangzhou 310058, China

e-mail: w_jyang@cls.zju.edu.cn

D.-C. Li

College of Life Sciences, Kim Il Sung University,

Pyongyang, Democratic People's Republic of Korea

\section{Introduction}

Archaea, one of the three major groups of life forms, are a highly diverse and abundant group that includes many "extremophiles" that thrive in harsh environments, such as hot springs, salt lakes, and submarine volcanic habitats (Madigan et al. 2000; Eckburg et al. 2003). Current knowledge on stress genes in archaea is considerably more limited than that for bacteria and eukaryotes. The stress response in archaea was first studied in 1980, but it was not until 1991 that an archaeal stress gene (hsp70) was first cloned and sequenced (Macario et al. 1991; Klumpp and Baumeister 1998). Since then, several studies have focused on stress genes and their expression in archaea (Macario et al. 1999), but many aspects of the archaeal stress response are yet to be studied. Sulfolobus solfataricus $P 2$ is a very widely studied crenarchaeal organism that grows well in the low $\mathrm{pH}$, high sulfur environment of volcanic hot springs. It is used as a model organism in archaeal research to study processes such as DNA replication, cell cycle, chromosomal integration, and RNA processing (She et al. 2001; Nicholas et al. 2004). The optimum temperature for $S$. solfataricus $P 2$ is about $75^{\circ} \mathrm{C}$, although it can live between $55^{\circ} \mathrm{C}$ and $90^{\circ} \mathrm{C}$ and in a $\mathrm{pH}$ range of $0.9-5.8$, with its optimum $\mathrm{pH}$ being 2-3. The genome of $S$. solfataricus $P 2$ was sequenced in 2001. It consists of a single circular chromosome of 2,992,245 base pairs, with 3,032 genes encoding 2,977 proteins (Ehrnsperger et al. 1997; Jakob et al. 1993; chang et al. 1996). Heat shock proteins (HSPs) are ubiquitously expressed cellular proteins that form a major, conserved protein family. Some HSPs are expressed constitutively under physiological conditions (Lindquist and Craig 1998; Haslbeck et al. 2005), while others are induced in response to chemical or physical stressors such as heat, heavy metals, oxidative stress, ethanol (Charles et al. 1996; Laszlo and Li 1993; Sun et al. 2007). 
Small heat shock proteins (sHSPs) are a family of stressinducible molecular chaperones that range in size from 12 to 43 kDa (Arrigo 1998; Ehrnsperger et al. 1998; MacRae 2000; Van Montfort et al. 2001) and that form oligomers consisting 9 to 50 subunits (Boston et al. 1996; Waters et al. 1996; She et al. 2001). The ability of sHSPs to form oligomers contributes to their thermal stability and ability to avoid denaturation in response to high temperatures. sHSPs have chaperone-like activity in vitro and protect organisms from various stresses. At denaturing temperatures, sHSPs can prevent the aggregation of proteins by binding to, and forming a stable complex with, folding intermediates of their substrate proteins. In some cases, sHSPs can also promote renaturation of unfolded polypeptides (Brock et al. 1972; Esposito et al. 1998). In this study, we subcloned the coding sequence of the small heat shock protein, HSP20 (SSO2427) from the thermoacidophilic archaeon $S$. solfataricus $P 2$ into a bacterial expression vector and produced recombinant protein for structural and functional analysis. To investigate the level of HSP20 mRNA in $S$. solfataricus $P 2$, we measured its mRNA expression profile in response to variations in culture temperature, including cold shock. Escherichia coli transformed with HSP20 was protected from a thermal stress of $50^{\circ} \mathrm{C}$ and cold stress of $4^{\circ} \mathrm{C}$. Purified S.so-HSP20 behaved as a molecular chaperone by inhibiting the thermal aggregation of citrate synthase and insulin B chain. These results indicate that HSP20 plays an important role in the response to thermal stress.

\section{Materials and methods}

Culturing S. solfataricus $P 2$ at different temperature and cold-shock treatment

For the cultivation of $S$. solfataricus $P 2$, a standard culture medium (yeast extract, $2.0 \mathrm{~g} ; \mathrm{KH}_{2} \mathrm{PO}_{4}, 3.10 \mathrm{~g}$; $\left(\mathrm{NH}_{4}\right)_{2} \mathrm{SO}_{4}$, $2.50 \mathrm{~g} ; \mathrm{MgSO}_{4} \times 7 \mathrm{H}_{2} \mathrm{O}, 0.20 \mathrm{~g} ; \mathrm{CaCl}_{2} \times 2 \mathrm{H}_{2} \mathrm{O}, 0.25 \mathrm{~g}$; Distilled water, $1,000.00 \mathrm{ml}$ ) was used. The $\mathrm{pH}$ of the medium was adjusted to 3.5 at room temperature with $10 \mathrm{~N}$ $\mathrm{H}_{2} \mathrm{SO}_{4}$ prior to autoclaving. $S$. solfataricus $P 2$ was cultured at different temperatures $\left(60^{\circ} \mathrm{C}, 75^{\circ} \mathrm{C}, 80^{\circ} \mathrm{C}\right)$. The cells were harvested during the $\log$ growth phase at an $\mathrm{OD}_{600}=$ 0.6. For cold-shock treatment, $S$. solfataricus $P 2$ was exposed to $4^{\circ} \mathrm{C}$ for $2 \mathrm{~h}$ after culturing at $75^{\circ} \mathrm{C}$.

\section{RNA extraction}

All samples were homogenized in Trizol Reagent (Invitrogen, CA, USA), and total RNA was prepared according to the manufacturer's instructions. Total RNA was quantified on a Genova UV/visible spectrophotometer at $260 \mathrm{~nm}$.
Measurement of S.so-HSP20 expression by quantitative real-time PCR

Complementary DNA was synthesized from $2 \mu \mathrm{g}$ of total RNA from each sample using random decamer primers and Murine Molony Leukemia Virus reverse transcriptase (Promega, Madison, WI, USA) in a $25-\mu l$ reaction. The expression pattern of S.so-HSP20 was analyzed in various samples using gene-specific primers HSP20RT-F, HSP20RT$\mathrm{R}$ (Table 1) and the MiniOpticon TM System (Bio-Rad, USA). Each polymerase chain reaction (PCR) reaction mix contained $12.5 \mu \mathrm{l}$ of Supermix, $10 \mu \mathrm{M}$ primer HSP20RT-F, $10 \mathrm{M}$ primer HSP20RT-R, and $1 \mu \mathrm{l}$ RT-products. PCR products were detected using the iQ SYBR Green Supermix kit (Bio-Rad). A standard curve was constructed using tenfold serial dilutions $\left(1: 10^{4}, 1: 10^{5}, 1: 10^{6}, 1: 10^{7}\right.$, and 1 : $10^{8}$ ) of purified plasmids subcloned with S.so-HSP20 together with a non-template control. A standard curve for NusG (Samson et al. 2008, 2011) was constructed using a purified plasmid subcloned with the NusG gene fragment that had been amplified with primers NusGF and NusGR (Table 1). This plasmid was then diluted in a tenfold series $\left(1: 10^{5}, 1: 10^{6}, 1: 10^{7}, 1: 10^{8}\right.$, and $\left.1: 10^{9}\right)$. All samples were analyzed in triplicate. Statistical significance was performed using the two-tailed paired Student's $t$ test. S.so-HSP20 gene expression profiles obtained from real-time PCR were normalized with the NusG transcript to correct for differences in the starting amount of RNA and in the efficiency of the reverse transcription reactions. Melting curve analysis of the PCR reaction was performed to assess specificity.

Genomic DNA extraction and plasmid purification

S. solfataricus $P 2$ was cultured at $75^{\circ} \mathrm{C}$ for 2 days using a standard culture medium. Cells were collected from $30 \mathrm{ml}$ of culture by centrifugation at $4,200 \times \mathrm{g}$ for $10 \mathrm{~min}$. $S$. solfataricus $P 2$ genomic DNA and Plasmids (Table 2) were extracted and purified using EZ-10 Spin Column Genome DNA isolation Kit, EZ-10 Spin Column Plasmid Mini-

Table 1 Primers used in this work

\begin{tabular}{ll}
\hline Primer & Sequence $\left(5^{\prime}-3^{\prime}\right)$ \\
\hline HSP20F & CGggatccATGCCCAAGAGGGAAGAAAAGGATA \\
HSP20R & CCGctcgagTTACTCAACTTTTATGTCAACACCA \\
NusGF & GTGGTTGGAGGGCAAGAAATAA \\
NusG & GGGACCAGAAATTACTTCTACTACATC \\
HSP20RT-F & CAGACGGTGTGCCGAAAATAG \\
HSP20RT-R & TAGCCTTAGCCGCCTTCTCG
\end{tabular}

Lowercase letters indicate restriction endonuclease recognition sequences (BamHI, XhoI) 
Table 2 Strains and plasmids used in this work
*HSP20, NCBI reference sequence: NP_343781.1 (She et al. 20001)

\begin{tabular}{|c|c|c|}
\hline Strain or plasmid & Relevant genotype or features & Reference \\
\hline \multicolumn{3}{|l|}{ Strains } \\
\hline Sulfolobus solfataricus p2 & Sulfolobus solfataricus DSMZ1617 & DSMZ \\
\hline E.coli BL21(DE3) & E.coli $\mathrm{B}(\mathrm{DE} 3)\left[\mathrm{F}^{-} \mathrm{dcm}\right.$ ompT hsdS $\left.\mathrm{B}_{\mathrm{B}}\left(\mathrm{r}_{\mathrm{B}}{ }^{-} \mathrm{m}_{\mathrm{B}}{ }^{-}\right)\right]$ & Studier et al. 1990 \\
\hline E.coli $\mathrm{P}$ & E.coli BL21(DE3) with pET-28a & This work \\
\hline E.coli $\mathrm{H}$ & E.coli BL21(DE3) with pET-28a-HSP20 & This work \\
\hline E.coli $\mathrm{HR}$ & E.coli $\mathrm{DH} 5 \alpha$ with pUCm-T-HSP-RT & This work \\
\hline E.coli $\mathrm{NusG}$ & E.coli $\mathrm{DH} 5 \alpha$ with pUCm-T-NusG-RT & This work \\
\hline \multicolumn{3}{|l|}{ Plasmids } \\
\hline pET-28a-HSP20 & pET28a $(+)$ with HSP20* & This work \\
\hline pUCm-T-HSP-RT & pUCm-T with HSP-RT DNA & This work \\
\hline pUCm-T-NusG & pUCm-T with NusG-RT DNA & This work \\
\hline
\end{tabular}

Preps Kit and EZ-10 Spin Column Gel Extraction Kit (BIO BASIC INC). All samples were prepared according to the manufacturer's instructions and DNA concentration was measured using a Genova UV/visible spectrophotometer at $260 \mathrm{~nm}$.

Cloning, expression, and purification of recombinant S.so-HSP20

The open reading frame of S.so-HSP20 was amplified from the chromosomal DNA of $S$. solfataricus $P 2$. The forward primer (HSP20F) contained a BamH I site (indicated lowercase, Table 1) and the reverse primer (HSP20R) contained a unique XhoI site (indicated lowercase, Table 1) with stop codon. The PCR product was digested with BamHI and XhoI, and ligated into the pET-28a vector (Novogen, USA) digested with BamHI and XhoI, generating pET-28a-S.so-HSP20, which encodes S.so-HSP20 with an N-terminal His6 extension. pET-28a-S.so-HSP20 was transformed into E. coli BL21 (DE3), and His6-S.so-HSP20 was induced by addition of isopropyl- $\beta$-D-Thiogalactoside (IPTG; $1-\mathrm{mM}$ final concentration) to exponentially growing cultures of E. coli (pET-28a-S.so-HSP20) in Lauria-Bertani (LB) medium containing $50 \mu \mathrm{g} / \mathrm{ml}$ of kanamycin. His6tagged protein was purified by Ni-NTA (Qiagen, USA) according to the manufacturer's instructions. S.so-HSP20 was purified to homogeneity, based on Coomassie blue staining after sodium dodecyl sulfate-polyacrylamide gel electrophoresis.

Thermotolerance experiments with transformed E. coli

For thermotolerance experiments, E. coli (pET-28a-S.soHSP20) was cultured as described above. IPTG (1 mM) was added to mid-log phase cultures $\left(\mathrm{OD}_{600}=0.8\right)$, and the cells were incubated at $30^{\circ} \mathrm{C}$ for $2 \mathrm{~h}$. The cultures were incubated at $50^{\circ} \mathrm{C}$ for $0,15,30,45$, and $60 \mathrm{~min}$ and at $4{ }^{\circ} \mathrm{C}$ for $1,2,3$, and $4 \mathrm{~d}$. The cultures were then diluted to $5.0 \times 10^{6}$ cells $/ \mathrm{ml}$ and $50 \mu \mathrm{l}$ samples were plated in triplicate on LB plates containing $50 \mu \mathrm{g} / \mathrm{ml}$ of kanamycin. The plates were incubated overnight at $37^{\circ} \mathrm{C}$ before scoring colony formation to determine the percentage of survivors. For each treatment, the proportion of surviving $E$. coli colonies was calculated by dividing the number of viable cells per plate in the treated samples versus untreated samples (no exposure to heat or cold shock). All samples were analyzed in triplicate. Statistical significance was performed using the two-tailed paired Student's $t$ test.

Assay of molecular chaperone activity

Citrate synthase (Sigma, USA) was diluted with $40 \mathrm{mM}$ HEPES (4-(2-hydroxyethyl)-1-piperazineethanesulfonic acid) $\mathrm{KOH}$ buffer at $\mathrm{pH} 7.5$ to a final concentration of $150 \mathrm{nM}$ in $1.0-\mathrm{ml}$ cuvettes and heated at $43^{\circ} \mathrm{C}$ with $150 \mathrm{nM}$ or $300 \mathrm{nM}$ of purified S.so-HSP20 or at $45^{\circ} \mathrm{C}$ with $150 \mathrm{nM}$ of purified S.so-HSP20. Aggregation of citrate synthase was monitored by measuring turbidity at 360 and $320 \mathrm{~nm}$ with a SPECTRA Max PLUS spectrophotometer every 5 and $10 \min$ for $1 \mathrm{~h}$. Bovine serum albumin (BSA) was used at $150 \mathrm{nM}$ to evaluate non-specific protection of citrate synthase (Chen et al. 2007). Chaperone-like activity of S.so-HSP20 was determined by measuring its ability to prevent dithiothreitol (DTT)-induced aggregation of insulin B chain in $50 \mathrm{mM}$ Tris- $\mathrm{HCl}$ (pH 7.4) buffer with $0.15 \mathrm{M} \mathrm{NaCl}$ for $25 \mathrm{~min}$ at $40^{\circ} \mathrm{C}$. The DTT was used at a final concentration of $20 \mathrm{mM}$. The turbidity of insulin B chain was measured using a SPECTRA max PLUS spectrophotometer at $360 \mathrm{~nm}$. The ratio of S.so-HSP20 to insulin concentration for the assay was 1:2. 


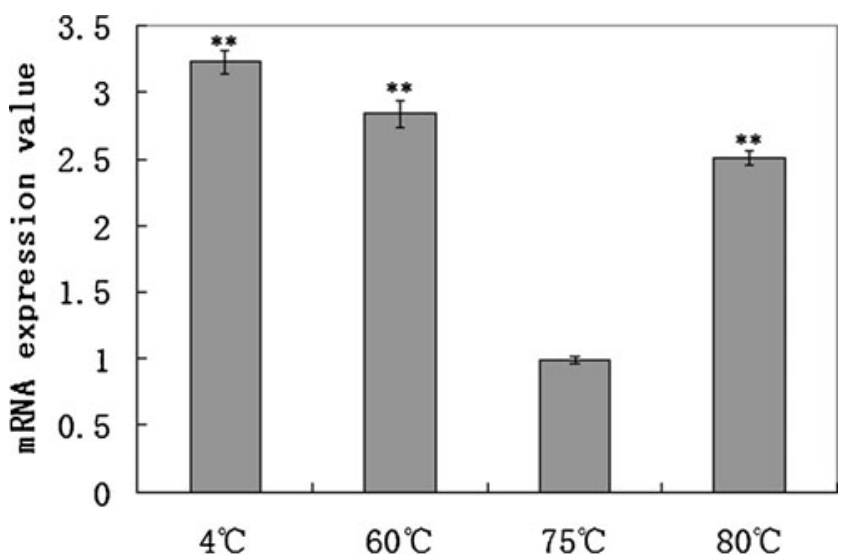

Fig. 1 S.so-HSP20 mRNA expression in S. solfataricus $P 2$ analyzed by real-time PCR. The level of S.so-HSP20 mRNA was measured in cells cultured at the indicated growth temperature or cold shock at $4{ }^{\circ} \mathrm{C}$ for $2 \mathrm{~h}$, and normalized against NusG (Internal control) levels. The mRNA expression value at $75^{\circ} \mathrm{C}$ was set to 1 and the other values were normalized against this. Data are representative of three trials and were expressed as the mean \pm SEM. Statistical significance was performed using the two-tailed paired Student's $t$ test. $\left({ }^{* *} p<0.01\right)$

\section{Results}

S.so-HSP20 mRNA expression in $S$. solfataricus $P 2$ at different growth temperatures and under cold-shock conditions

The expression of S.so-HSP20 mRNA in S. solfataricus $P 2$ was measured at different culture temperatures (Fig. 1). S. so-HSP20 mRNA expression was strongly increased at culture temperatures far from the optimal growth temperature of $75^{\circ} \mathrm{C}$. The increases in S.so-HSP20 mRNA expression at temperatures that were lower $\left(60^{\circ} \mathrm{C}\right)$ or higher

a

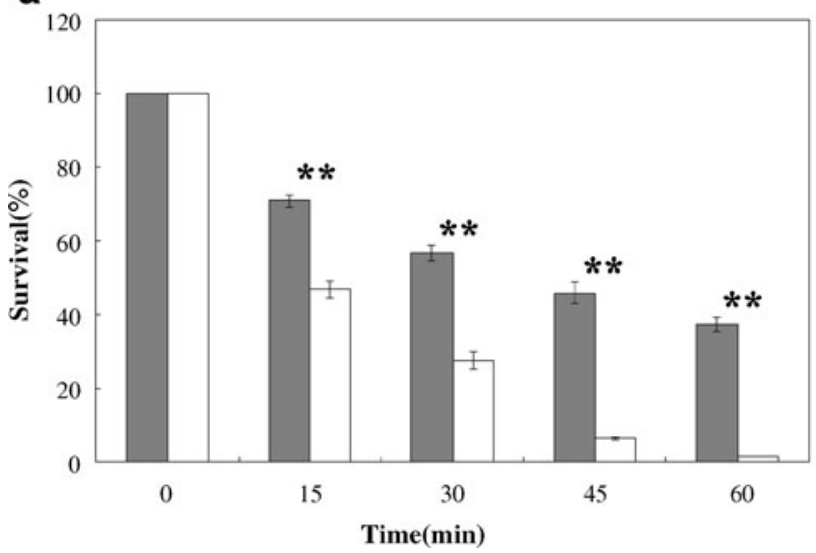

Fig. 2 Thermotolerance assays were performed at $50^{\circ} \mathrm{C}$ (a) and $4{ }^{\circ} \mathrm{C}$ (b). E. coli $\mathrm{P}$ (with pET-28a) and E. coli $\mathrm{H}$ (with pET-28a-S.so-HSP20) were cultured as described and subjected to $50^{\circ} \mathrm{C}$ treatment for up to $60 \mathrm{~min}$ and $4^{\circ} \mathrm{C}$ treatment for up to 4 days. After heat or cold treatment, samples were taken at the time indicated, diluted, and immediately plated on LB plates with kanamycin. Survival of $E$. coli $\left(80^{\circ} \mathrm{C}\right)$ than the optimum culture temperature $\left(75^{\circ} \mathrm{C}\right)$ were 2.83- and 2.5-fold, respectively. S.so-HSP20 mRNA expression also increased 3.23-fold in response to coldshock treatment $\left(4^{\circ} \mathrm{C}\right)$.

Survival after thermal stress in E. coli expressing S.so-HSP20

To determine whether S.so-HSP20 could enhance the thermotolerance of $E$. coli, the effect of heat stress on the growth of $E$. coli cells transformed with S.so-HSP20 was examined. E. coli expressing S.so-HSP20 was more resistant to heat stress than cells containing only the pET28 a vector. As shown in Fig. 2, after exposure to $50^{\circ} \mathrm{C}$, the survival of cells transformed with pET-28a only dropped to about $1.5 \%$ at $1 \mathrm{~h}$, whereas that of the cells with pET-28a-S. so-HSP20 was $37.9 \%$. Transformation with S.so-HSP20 also protected $E$. coli from exposure to cold $\left(4^{\circ} \mathrm{C}\right)$, with survival recorded as $18.8 \%$ after 3-days cold exposure, compared to just $1.2 \%$ in E. coli transformed with pET-28a only. These results show that expression of S.so-HSP20 in $E$. coli cells increases cellular thermotolerance.

\section{S.so-HSP20 exhibits chaperone activity in vitro}

A key characteristic of molecular chaperones is their ability to suppress the aggregation of non-native proteins. To test whether S.so-HSP20 exhibits chaperone activity, we performed thermal unfolding assays using citrate synthase and insulin B chain as model substrates (Figs. 3 and 4). Purified S.so-HSP20 effectively protected citrate synthase against heat-induced denaturation. At concentrations of 150 or $300 \mathrm{nM}$, S.so-HSP20 reduced heat-induced turbidity resulting from incubation at $43^{\circ} \mathrm{C}$ for $60 \mathrm{~min}$ by $48.1 \%$ and

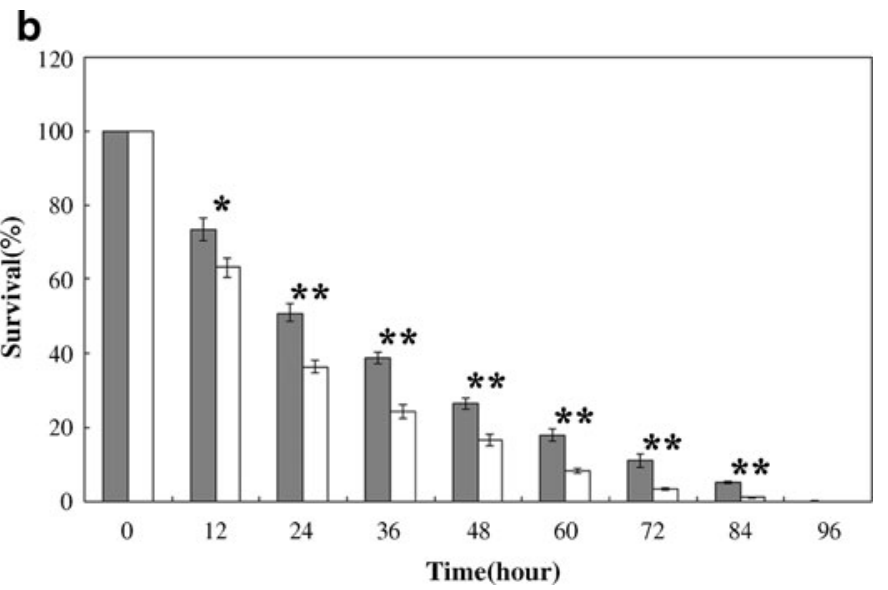

$\mathrm{H}$ cells (black boxes) and E. coli $\mathrm{P}$ cells (open boxes) are shown, and are expressed as a percentage of the survival obtained in LB plates. Data are representative of three trials and were expressed as the mean \pm SEM. Statistical significance was performed using the twotailed paired Student's $t$ test. $(* p<0.05 ; * * p<0.01)$ 

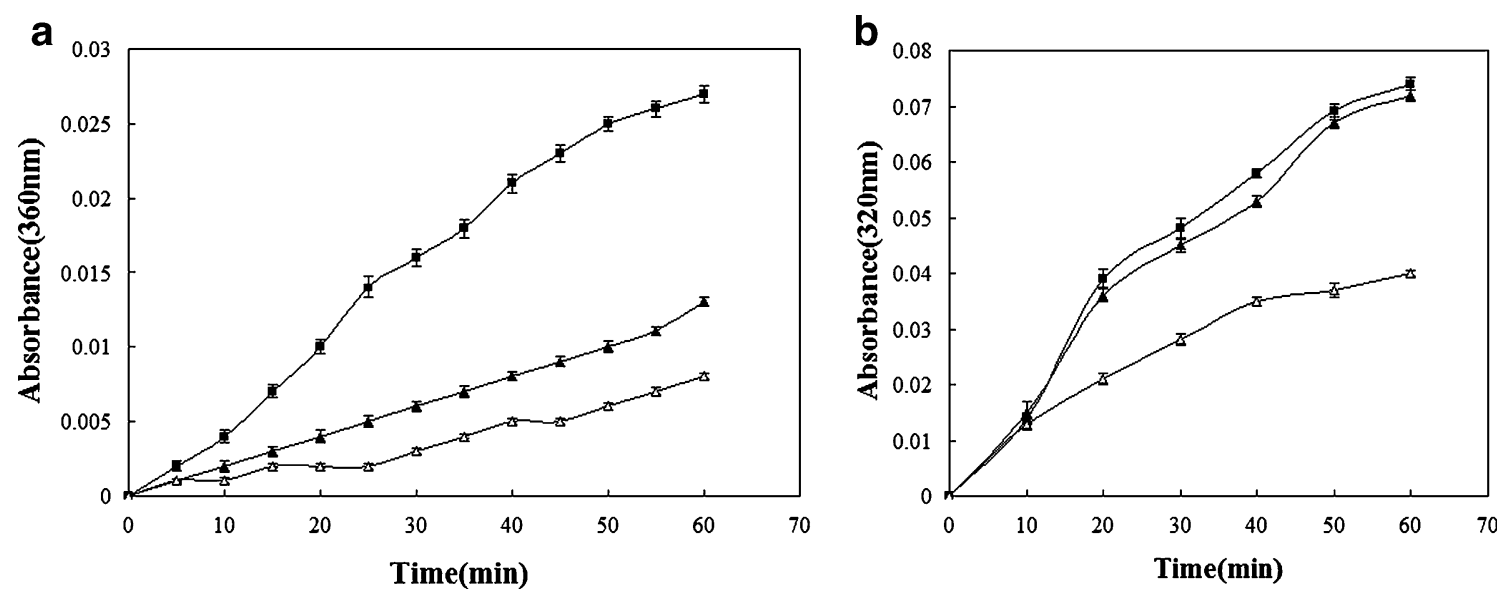

Fig. 3 S.so-HSP20 prevents heat-induced denaturation of citrate synthase. Purified S.so-HSP20 was incubated at $43^{\circ} \mathrm{C}$ (a) with $150 \mathrm{nM}$ citrate synthase, and turbidity was measured at $360 \mathrm{~nm}$. S. so-HSP20 concentrations were $0.0 \mathrm{nM}$ (black square), $150 \mathrm{nM}$ (black triangle), $300 \mathrm{nM}$ (open triangle). S.so-HSP20 was also incubated at

$70.4 \%$, respectively (Fig. 3a). Similarly, heat-induced turbidity resulting from a 60 -min incubation at $45^{\circ} \mathrm{C}$ was reduced by S.so-HSP20 by $38.3 \%$ (Fig. 3b). Heat-induced turbidity of the insulin B chain was reduced by S.so-HSP 20 by $47 \%$ after $24 \mathrm{~min}$ at $40^{\circ} \mathrm{C}$ (Fig. 4). These results demonstrate that S.soHSP20 exhibits chaperone activity in vitro.

\section{Discussion}

In the present study, we examined the thermotolerance and molecular chaperone properties of $S$. solfataricus $P 2$ sHSP, HSP20. The coding region of the HSP20 gene of the thermoacidophilic archaeon, $S$. solfataricus $P 2$, was cloned into a plasmid vector and overexpressed in bacteria. The

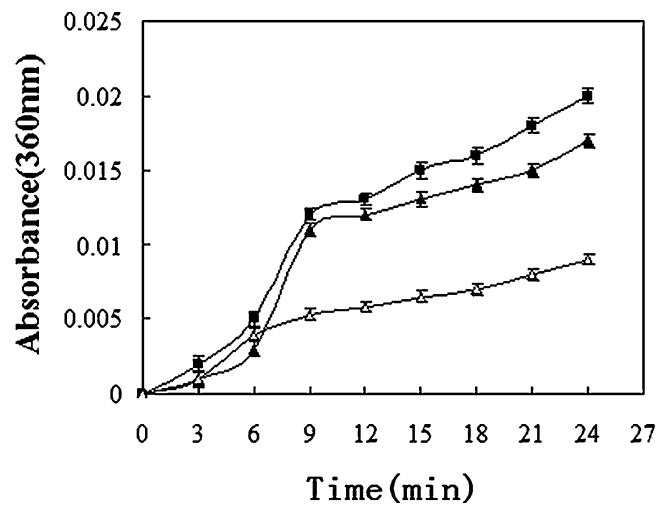

Fig. 4 S.so-HSP20 has chaperone-like activity. Chaperone-like activity of S.so-HSP20 was determined by measuring turbidity during DTT-induced aggregation of the insulin $B$ chain $(0.2 \mathrm{mg} / \mathrm{ml})$ for 24 min at $40^{\circ} \mathrm{C}$; insulin B chain alone (black triangle), insulin B chain in the presence of $0.2 \mathrm{mg} / \mathrm{ml} \mathrm{BSA} \mathrm{(black} \mathrm{square),} \mathrm{or} \mathrm{the} \mathrm{insulin} \mathrm{B}$ chain in the presence of $0.1 \mathrm{mg} / \mathrm{ml} \mathrm{S.so-HSP20}$ (open triangle). Data are representative of three trials and were expressed as the mean \pm SEM $45^{\circ} \mathrm{C}$ (b) with $150 \mathrm{nM}$ citrate synthase, and turbidity was measured at $320 \mathrm{~nm}$. The S.so-HSP20 concentration was $0.0 \mathrm{nM}$ (black triangle) or $150 \mathrm{nM}$ (open triangle). BSA at $150 \mathrm{nM}$ (black square) was used as a control. Data are representative of three trials and were expressed as the mean \pm SEM

recombinant protein was used for structural and functional analysis. We analyzed mRNA expression of HSP20 in response to different culture temperatures. Many sHSPs are not constitutively expressed, and their expression is induced specifically in response to stress conditions, such as elevated temperatures. We found that the expression of $\mathrm{S}$. so-HSP20 mRNA is markedly increased following culture of $S$. solfataricus $P 2$ at temperatures far from the optimal growth temperature. This result suggests that S.so-HSP20 mRNA expression is stress-induced, and may protect $S$. solfataricus $P 2$ from stress. Expression of S.so-HSP20 in $E$. coli also protected these cells from temperature stress including cold shock. E.coli HSPs have been suggested to play a major role in protecting cells from thermal killing. The function of S.so-HSP20 in E. coli may be to promote thermotolerance by enhancing protein synthesis in $E$. coli (including HSPs) or by protecting E. coli proteins from heat denaturation through its chaperone activity. We demonstrated chaperone activity for S.so-HSP20 of $S$. solfataricus $P 2$ at physiological and heat shock temperatures. The ability of S.so-HSP20 to protect against heat-induced aggregation of citrate synthase (Keisuke et al. 2001; Ding et al. 2008; Martin et al. 2008; Angelo et al. 2004) and insulin B chain (Azzoni et al. 2004; Satoru 2006) indicates that S.so-HSP20 possesses chaperone activity and the ability to recognize and bind unfolded proteins to prevent their aggregation in vitro. The relationship between cellular thermotolerance and S.so-HSP20 expression in an E. coli expression system has not previously been reported. The results of this study provide evidence that S.so-HSP20 can protect E. coli from thermostress and behave as a chaperone in vitro. Future studies will develop an S.so-HSP20 expression system in Sacharomyses cerevisiae, and will assess the ability of S.soHSP20 to regulate apoptosis. 
Open Access This article is distributed under the terms of the Creative Commons Attribution Noncommercial License which permits any noncommercial use, distribution, and reproduction in any medium, provided the original author(s) and source are credited.

\section{References}

Angelo K, Burr GA, John JH (2004) Molecular chaperone function of the Rana catesbeiana small heat shock protein, hsp30. Compar Biochem Phys Part A 139:175-182

Arrigo AP (1998) Small stress proteins: chaperones that act as regulators of intracellular redox state and programmed cell death. Biol Chem 379:19-26

Azzoni AR, Tada SF, Rosselli LK et al (2004) Expression and purification of a small heat shock protein from the plant pathogen Xylella fastidiosa. Protein Expr Purif 33(2):297-303

Boston RS, Viitanen PV, Vierling E (1996) Molecular chaperones and protein folding in plants. Plant Mol Biol 32:191-222

Brock T, Brock K, Belly R et al (1972) Sulfolobus: A new genus of sulfur-oxidizing bacteria living at low $\mathrm{pH}$ and high temperature. Arch Microbiol 84:54-68

Chang Z, Primm TP, Jakana J et al (1996) Mycobacterium tuberculosis $16-\mathrm{kDa}$ antigen (Hsp 16.3) functions as an oligomeric structure in vitro to suppress thermal aggregation. J Biol Chem 271:7218-7223

Charles JC, Stefan WR, Angela F et al (1996) Photodynamic therapymediated oxidative stress can induce expression of heat shock proteins. Cancer Res 56:2355-2360

Chen T, Villeneuve TS, Garant KA et al (2007) Functional characterization of artemin, a ferritin homolog synthesized in artemia embryos during encystment and diapause. FEBS J 274:1093-1101

Ding X, Lv ZM, Zhao Y et al (2008) MTH1745, a protein disulfide isomerase-like protein from thermophilic archaea, Methanothermobacter thermoautotrophicum involving in stress response. Cell Stress and Chaperones 13:239-246

Eckburg PB, Lepp PW, Relman DA (2003) Archaea and their potential role in human disease. Infect Immun 71(2):591-596

Ehrnsperger M, Graber S, Gaestel M et al (1997) Binding of nonnativeprotein to Hsp25 during heat shock creates a reservoir of folding intermediates for reactivation. EMBO J 16:221-229

Ehrnsperger M, Hergersberg C, Wienjues U et al (1998) Stabilization of proteins and peptides in diagnostic immuno-logical assays by the molecular chaperone hsp25. Anal Biochem 259:218-225

Esposito L, Sica F, Sorrentino G et al (1998) Protein crystal growth in the advanced protein crystallization facility on the LMS mission: a comparison of Sulfolobus solfataricus alcohol dehydrogenase crystals grown on the ground and in microgravity. Biol Crystallogr 54:386-390

Haslbeck M, Franzmann T, Weinfurtner D et al (2005) Some like it hot: the structure and unction of small heat-shock proteins. Nat Struct Mol Biol 12:842-846

Jakob U, Gaestel M, Engel K et al (1993) Small heat shock proteins are molecular chaperones. J Biol Chem 268:1517-1520
Keisuke U, Takao Y, Tadashi M et al (2001) Small heat shock protein of a hyperthermophilic archaeum, Thermococcus sp. strain KS- 1, exists as a spherical 24 mer and its expression is highly induced under heat-stress conditions. J Biosci Bioeng 92(2):161166

Klumpp M, Baumeister W (1998) The thermosome: archetype of group II chaperonins. FEBS J 430:73-77

Laszlo A, Li GC (1993) Effect of amino acid analogs on the development of thermotolerance and on thermotolerant cells. J Cell Physiol 154:419-432

Lindquist S, Craig EA (1998) The heat-shock proteins. Annu Rev Genet 22:631-677

Macario AJ, Dugan CB, Conway ME (1991) A dnaK homolog in the archaebacterium Methanosarcina mazei S6. Gene 108(1):133137

Macario AJL, Lange M, Ahring BK et al (1999) Stress genes and proteins in the Archaea. Microbiol Mol Biol Rev 63:923967

MacRae TH (2000) Structure and function of small heat shock/acrystallin proteins: established concepts and emerging ideas. Cell Mol Life Sci 57:899-913

Madigan MT, Martinko JM, Parker J (2000) Prokaryotic diversity: the Archaea. In: Brock biology of microorganisms. Prentice-Hall, Inc., Upper Saddle River, pp 546-572

Martin H, Andreas K, Johannes B et al (2008) Structural dynamics of archaeal small heat shock proteins. J Mol Biol 378:362-374

Nicholas PR, Isabelle D, Magnus L et al (2004) Identification of two origins of replicationin the single chromosome of the archaeon Sulfolobus solfataricus. Cell 116:25-38

Samson RY, Obita T, Freund SM et al (2008) A role for the ESCRT system in cell division in Archaea. Science 322:1710-1713

Samson RY, Obita T, Hodgson B et al (2011) Molecular and structural basis of ESCRT-III recruitment to membranes during Archaeal cell division. Mol Cell 41:186-196

Satoru T (2006) Analytical assays of human HSP27 and thermal-stress survival of Escherichia coli cells that overexpress it. Biochem Biophys Res Commun 341:1252-1256

She Q, Singh RK, Confalonieri F et al (2001) The complete genome of the crenarchaeon Sulfolobus solfataricus P2. Proc Natl Acad Sci USA 98:7835-7840

Studier FW, Rosenberg AH, Dunn JJ et al (1990) Use of T7 RNA polymerase to direct expression of cloned genes. Meth Enzymol 185:60-89

Sun XK, Fontaine J-M, Bartl I et al (2007) Induction of Hsp22 (HspB8) by estrogen and the metalloestrogen cadmium in estrogen receptor-positive breast cancer cells. Cell Stress and Chaperones 12(4):307-319

Van Montfort R, Slingsby C, Vierling E (2001) Structure and function of the small heat shock protein/a-crystallin family of molecular chaperones. Adv Protein Chem 59:105-156

Waters ER, Lee GJ, Vierling E (1996) Evolution, structure and function of the small heat shock proteins in plants. J Exp Bot $47: 325-338$ 